\title{
A comparison of charcoal- and slag-based constructed wetlands for acid mine drainage remediation
}

\author{
Craig Sheridan*, Kevin Harding, Edward Koller and Antonio De Pretto \\ Industrial and Mining Water Research Unit, School of Chemical and Metallurgical Engineering, \\ University of the Witwatersrand, Private Bag 3, Wits, 2050, South Africa
}

\begin{abstract}
Subsurface-flow constructed wetlands (CW) with charcoal- or slag-based bed matrices were investigated for their potential use in remediating acid mine drainage (AMD). A CW is effectively a reactor in which some components of the wastewater are broken down by the organisms occurring within the $\mathrm{CW}$, whilst others may be degraded by physico-chemical processes or a combination thereof. Two $200 \ell$ small-scale CWs were built at the University. Commercially available charcoal and $<19 \mathrm{~mm}$ basic oxygen furnace (BOF) slag were used as the bed matrices and the units were planted with a variety of plants. The units were exposed to an artificial AMD. The results showed that the systems removed almost all soluble iron and more than $75 \%$ of the sulphate. Both CWs were able to increase the $\mathrm{pH}$ of the AMD.
\end{abstract}

Keywords: AMD, charcoal, slag, constructed wetlands, remediation

\section{INTRODUCTION}

\section{Background}

Acid mine drainage (AMD) is liquid drainage from existing or historic mining operations which is typically characterised by low $\mathrm{pH}$ and high concentrations of heavy metals such as iron and manganese, in addition to high sulphate concentrations (Peppas et al., 2000; Potgieter-Vermaak et al., 2006). It is mainly associated with mining and quarrying, and is formed when sulphide-bearing minerals are oxidised in the presence of water and oxygen (Potgieter-Vermaak et al., 2006; Akcil and Koldas, 2006; Lindsay et al., 2011). In the AMD formation process, water which passes through abandoned or existing mines, tailings dumps or waste rock, reacts with the exposed iron-sulphide minerals. These iron-sulphide minerals are oxidised, usually by oxygen, resulting in acidic, sulphate-rich liquid being formed, with iron and other heavy metals present in their soluble form (Ziemkiewicz, 1998; Potgieter-Vermaak et al., 2006). The metal content of AMD is a result of the type and composition of the material found in the mineral being oxidised (Akcil and Koldas, 2006).

AMD has long been considered an environmental hazard (Sheoran and Sheoran, 2006) and can cause long-term damage to waterways and to the biodiversity of ecosystems that rely on these waterways (Akcil and Koldas, 2006). In addition to its acidic nature, some AMD effluents contain cyanides, and/or heavy and toxic metals. In literature, it has been proposed that the heavy metal content of AMD is of greater environmental concern than the acidity of the effluent (Sheoran and Sheoran, 2006). AMD presents a particular problem for South Africa, where large deposits of natural reserves, most notably gold and

This paper was originally presented at the 2012 Water Institute of Southern Africa (WISA) Biennial Conference, Cape Town, 6-10 May 2012.

* To whom all correspondence should be addressed.

픈 +27 11 717-7592; e-mail: craig.sheridan@wits.ac.za coal, occur (SouthAfrica.info, 2013). As such, mining of these resources is one of the largest industries in the country. The current production of AMD is primarily as a result of current and historic coal and gold mining operations (PotgieterVermaak et al., 2006; Tutu et al., 2008). The extraction of these minerals from mines, whether open-pit or shaft, often results in wastewater and effluent (Akcil and Koldas, 2006). Furthermore, because of the high cost of treating AMD, a trend has developed in South Africa in which mining companies submit to the closure of an AMD-affected mine in an attempt to avoid costs associated with treating the AMD (Labuschagne et al., 2005). Within the Gauteng Province of South Africa, the presence of soluble, and hence mobile, uranium poses an additional threat to potentially impacted receptors of AMD (Tutu et al., 2008).

\section{Treating AMD}

\section{Treatment options}

Various strategies for AMD treatment and mitigation have been proposed including primary prevention (the prevention of acid-producing processes), secondary control (the prevention of acid migration or movement after formation) and tertiary control (the collection and treatment of effluent). Primary prevention is not always feasible as the prediction of the potential of a process to create AMD is exceedingly challenging and costly (USEPA, 1994). Furthermore, this would vary from site to site and between mines as the AMD compositions frequently differ. Secondary control is often not feasible as there is no standardised method for ranking, measuring, and reducing AMD (Akcil and Koldas, 2006). Tertiary control is typically conducted by a number of different methods including, but not limited to, lime neutralisation (Sheoran and Sheoran, 2006), Gypsum cation-anion exchange (Akcil and Koldas, 2006), reverse osmosis (Squires et al. 1983), etc. However, active treatment is expensive and, as such; AMD is often left untreated (Diz, 1997). Thus, there is a need for a cheap, effective passive treatment system which is efficient at removing AMD. 


\section{Passive treatment systems}

Passive treatment systems have been used for many years to treat mine effluents of varying compositions and $\mathrm{pH}$ levels (Dvorak et al., 1992; Younger, 1997). It has been shown that passive treatment is possible using the process of dissimilatory sulphate reduction (DSR) coupled with organic carbon reduction (Tuttle et al., 1969). According to the literature (Lindsay et al., 2011), sulphate-reducing bacteria (SRB) form the catalyst in the DSR process, consuming organic carbon $\left(\mathrm{CH}_{2} \mathrm{O}\right.$, for example) under strictly anaerobic conditions according Eq. (1) below:

$$
\mathrm{SO}_{4}^{2-}+2 \mathrm{CH}_{2} \mathrm{O} \rightarrow \mathrm{H}_{2} \mathrm{~S}+2 \mathrm{HCO}_{3}^{-}
$$

The generation of bicarbonate by this reaction increases the alkalinity. Further, the production of $\mathrm{H}_{2} \mathrm{~S}$ promotes the removal of metals which have low solubility products as metal sulphides, such as the ferrous ion $\left(\mathrm{Fe}^{2+}\right)$. The action of DSR and metal-sulphide precipitation has been shown to reduce the aqueous concentration of $\mathrm{Fe}, \mathrm{Cu}, \mathrm{Pb}, \mathrm{Zn}$ and $\mathrm{Ni}$ (Waybrandt et al. 1998; Benner et al. 1999). It has been observed that the rate of sulphate reduction by SRB is strongly affected by nutrient availability, particularly the availability of carbon (Benner et al., 2000). Therefore, there must be an organic carbon amendment to the reacting system. Particular passive treatment systems which have been utilised for DSR include anaerobic bioreactors (Dvorak et al., 1992; Christensen et al., 1996), anaerobic wetlands (Kadlec et al., 2000), and reactive permeable barriers (Waybrandt et al., 1998). All of these technologies have been applied to AMD treatment. In this study, the use of amended constructed wetlands as a potential remedial strategy for AMD was investigated.

\section{Amended constructed wetlands}

Constructed wetlands are attached-growth biofilters/bioreactors which utilise vegetation specially adapted to grow in an environment of complete or near-saturation of the vadose zone (Wallace et al., 2006). Historically, constructed wetlands have been applied to AMD (Kadlec et al., 2000; Wallace and Knight, 2000), with most of the applications at abandoned or disused coal mines (Ziemkiewicz, 1998; Batty and Younger, 2004), or for the removal of iron and/or manganese from mine effluent streams (Wallace and Knight 2006). The effect of vegetation is an important parameter in constructed wetlands used to treat metal-contaminated water (Batty, 2003), since plants are able to remove dissolved metals from water via the process of rhizofiltration (Dushenkov et al., 1995). However, vegetation has proved difficult to establish in AMD treatment applications due to the low $\mathrm{pH}$ (Batty and Younger, 2004).

Various organic carbon sources, such as wood chips, livestock manure, winery waste, crop residues, organic soil, municipal compost, municipal biosolids and grain mill byproducts have been used as carbon amendments for treating AMD (Lindsay et al., 2011; Tuttle et al. 1969; Christensen et al. 1996). The influence of various carbon sources on the passive remediation of the mill-tailings pore-water of a disused silverzinc-lead-gold mine was investigated. Various mixtures of peat, spent brewing grain and municipal biosolids were found to promote DSR and metal-sulphide precipitation (Lindsay et al., 2011), while decreasing the aqueous concentrations of zinc, thallium, manganese, nickel and antimony (Lindsay et al., 2011). The investigators concluded that the use of an organic carbon amendment in treating AMD was necessary for the effectiveness of long-term treatment.

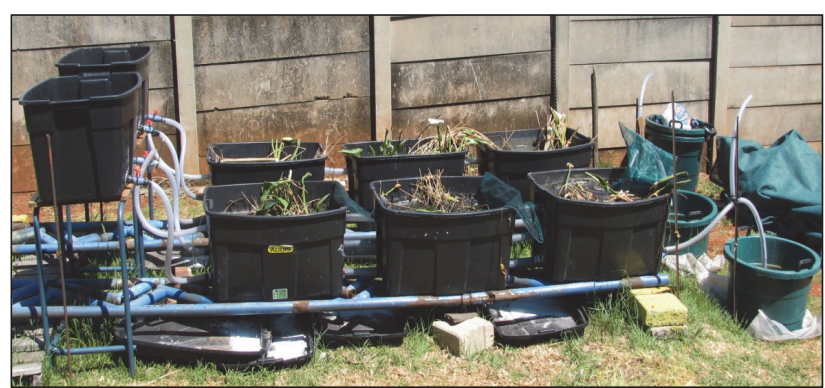

Figure 1

Constructed wetlands as used in this work

Alternative AMD-neutralising agents have also been reported in the literature (Potgieter-Vermaak et al., 2006; Ziemkiewicz, 1998; Feng et al., 2004; Yokley and Lancet, 1987). A study on the use of steel slag in AMD remediation was conducted (Ziemkiewicz, 1998). Steel slags are effectively a mixture of soluble calcium and manganese oxides encased in a glassy calcium-alumino-silicate matrix. It was found that steel slags tend to generate high levels of alkalinity over time, and also exhibit high acid neutralisation potentials. It was also found that steel slags are able to provide highly concentrated alkaline recharges to AMD. Further, steel slags retain a relatively high permeability to water, retain structural integrity when pelletized and packed, and do not absorb atmospheric carbon dioxide to form calcite, which implies that even steel slag which has been exposed to the elements for many years is still able to yield high levels of alkalinity (Ziemkiewicz, 1998). Thus, steel slag represents a viable amendment to a CW designed to treat AMD as it is able to provide a stable support medium for vegetation, as well as to effectively reduce acidity levels.

In this study the AMD remediation potential of two smallscale, constructed wetlands was investigated. The first was constructed with a bed matrix of basic oxygen furnace (BOF) slag and the second with commercially available charcoal. Charcoal was chosen as an amendment as it is stable, not prone to normal biodegradation processes and has an ion adsorption capacity. Both systems were planted with a mixture of plants, although primarily with Zantedeschia aethiopica (arum lily) and Cyperus papyrus (papyrus reed).

\section{EXPERIMENTAL PROCEDURES}

\section{Experimental apparatus}

Two experimental rigs consisting of 3 acrylonitrile-butadienestyrene tanks connected in series were constructed. The first rig was filled with $50 \mathrm{~kg}$ (in total) of hardwood charcoal (Ignite Products) and the other was filled with $70 \mathrm{~kg}$ (in total) of BOF slag, nominal particle diameter of $25 \mathrm{~mm}$ (Harsco Metals \& Minerals South Africa). Both the rigs were assumed to have a void fraction of approximately $40 \%$ and were then filled with tap water such that the effective liquid volume of water was $60 \mathrm{l}$. The CW was sparsely planted with Zantedeschia aethiopica and Cyperus papyrus. The rigs are shown in Fig. 1.

\section{Simulated acid mine drainage}

In Experiment 1, a simulated AMD (pH 4) was fed to the CWs and in Experiment 2, a lower $\mathrm{pH}$ simulated AMD ( $\mathrm{pH}$ 1.35) was fed to the CWs. In each experiment, the AMD was fed at 
$30 \mathrm{ml} / \mathrm{min}$ such that the AMD had a nominal residence time of 2.5 days. The simulated AMD was made according to the concentrations of Potgieter-Vermaak et al. (2006) and its composition is presented in Table 1.

\begin{tabular}{|l|c|c|}
\hline \multicolumn{3}{|c|}{ TABLE 1 } \\
Experiment 1 and 2 AMD feed composition \\
\hline AMD component & Experiment 1 & Experiment 2 \\
\hline $\mathrm{SO}_{4}^{2-}(\mathrm{mg} / \ell)$ & 6000 & 6000 \\
\hline $\mathrm{Fe}^{3+}(\mathrm{mg} / \ell)$ & 1500 & 1500 \\
\hline $\mathrm{Fe}^{2+}(\mathrm{mg} / \ell)$ & 500 & 500 \\
\hline $\mathrm{pH}$ & 4 & 1.35 \\
\hline
\end{tabular}

Upon feeding the AMD into the CWs, samples were taken from the outlets of the systems every $2 \mathrm{~h}$ from 08:00 to 20:00 for 3 days. The first sample of each run was taken as a control sample before the addition of the AMD. The samples were analysed for $\mathrm{pH}$, sulphate and total iron concentration. The $\mathrm{pH}$ was tested using universal indicator paper, while the sulphate and iron ion concentrations were analysed using the Merck test kits (No. 114791 for sulphate and No. 114761 for total iron) and the Merck Spectroquant. Each sample was analysed 3 times in the Spectroquant so as to obtain a representative mean concentration.

\section{RESULTS AND DISCUSSION}

\section{Diluting effect}

In the figures presented, the feed to the $\mathrm{CW}$ and the concentration at the outlet, as well as a value called 'diluted iron, diluted sulphate' etc., is shown. Since the rigs were initially filled with water, as the simulated AMD was fed into them, the water would have had a dilution effect. This diluting effect (as a maximum dilution) is presented as a comparison as this value would indicate that of zero remediation.

\section{Neutralisation of acidity}

The effect of charcoal and slag CW on the $\mathrm{pH}$ of treated AMD is shown in Fig. 2. The data indicate that the $\mathrm{pH}$ increased in the experiments, with the slag-based CW being more effective at increasing the $\mathrm{pH}$ to a value between 6.5 and 7 in both experiments. The charcoal-based $\mathrm{CW}$ raised the $\mathrm{pH}$ but not to the same extent as the slag-based CW. The temporal behaviour of the system indicated the CWs were less effective with increasing time. The steady-state values (if such exist) were not determined in this study and we are aware that this is a limitation of these experiments.

In terms of acidity reduction, the BOF slag amendment showed increased $\mathrm{pH}$-raising capacity compared to the charcoal CW. Regarding the CWs ability to treat AMD, it was observed that the wetland plants in both beds survived the moderate and low $\mathrm{pH}$ runs. As such, it is surmised that other wetland plants would also be able to treat the very acidic AMD, although it may prove difficult to establish the vegetation to be used under such conditions (Batty and Younger, 2004) and whether it would survive over extended periods.

\section{Iron and sulphate removal}

The results of iron and sulphate removal using the charcoal and slag CWs are presented in Fig. 3 and Fig. 4, respectively.

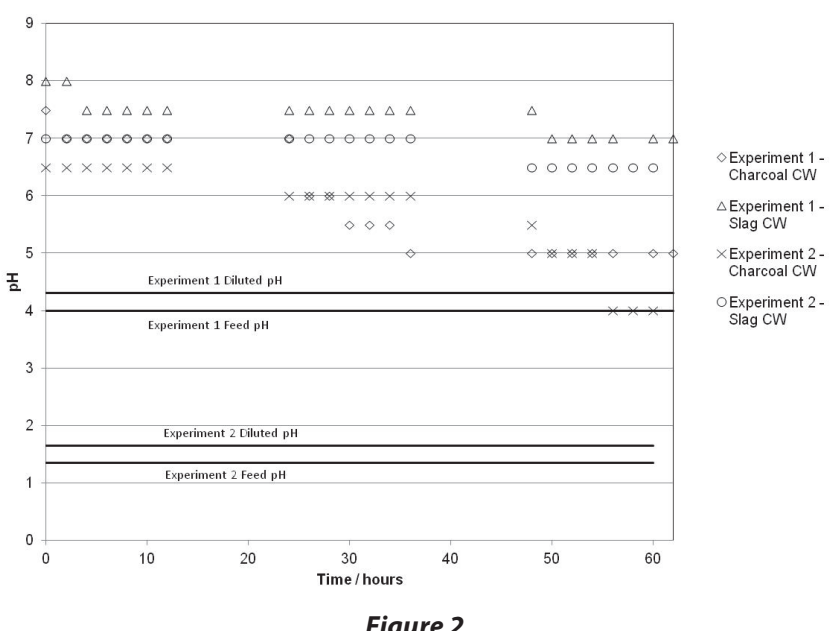

The effects of charcoal and slag on the pH of AMD treated using CWs

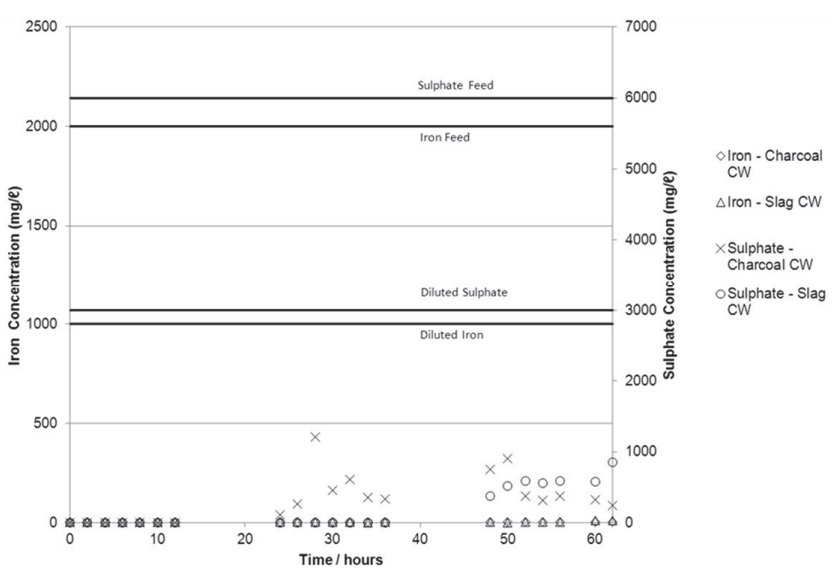

Figure 3

Sulphate and iron reduction within both slag and charcoal CWs for Experiment $1(\mathrm{pH}=4.5)$

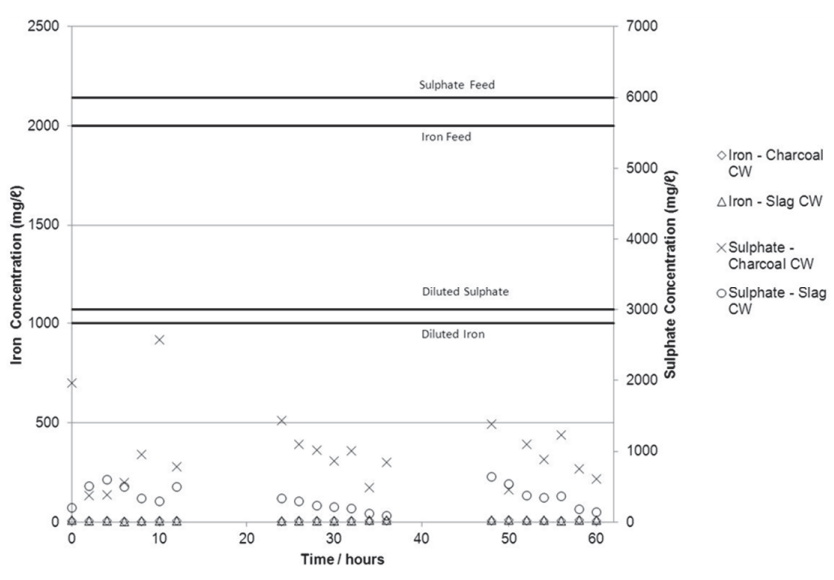

Figure 4

Sulphate and iron reduction within both slag and charcoal CWs for Experiment $2(\mathrm{pH}=1.35)$

\section{Iron removal}

It can be seen that in both experiments iron was effectively removed by the CWs from dissolved form. The iron exited the CW as an insoluble, red, turbid colouring in the outlet, which was most probably a suspension of iron oxides and hydroxides. The increase in pH (see Fig. 4) caused the precipitation of iron, an explanation supported by the Pourbaix 
diagram for iron. It is also possible that the adsorptive capacity of the charcoal aided in the removal of iron, although this was not tested in this experiment. The appearance of iron hydroxide precipitates was most probably due to the presence of iron-oxidising bacteria - particularly Sagittaria australis - which may have been present in the CW system (Emerson et al., 1999), although this has not been tested at this time. The appearance of iron hydroxide in the CW effluent indicated that the CW failed to effectively filter out the solid iron precipitate. This means that further treatment steps may be needed after the CW to effectively filter out iron precipitates, should such a CW be designed. If filtration were effective, clogging of the CW matrix could reduce the efficacy of the system with time.

\section{Sulphate removal}

Sulphate was removed in both systems to less than $25 \%$ of the input amount. A diurnal effect was observed which was suggestive of biological/microbial removal, and, indeed, during sampling a stench of $\mathrm{H}_{2} \mathrm{~S}$ gas emanating from both the charcoal and the slag CW was noted. Given the short duration of the experiment, it was not possible to conclusively determine which system was more effective at sulphate removal. It appears that at an initial $\mathrm{pH}$ of 1.35 , both systems were operating well by $60 \mathrm{~h}$, with the slag-based CW demonstrating better sulphate removal. At a higher $\mathrm{pH}$ of 4 , by $60 \mathrm{~h}$ it appeared that the charcoal-based CW was more effective at sulphate removal. Further work should be conducted to confirm this and to determine long-term trends.

The morning peaks observed in the sulphate levels, particularly in the charcoal-based bed, could possibly be explained by the diurnal activity of photosynthetic microorganisms and plants in the CW. The cycle of photosynthesis produces an organic carbon source which could be utilised by the SRB as a reactant in the DSR reaction (Eq. (1)). Photosynthetic organisms are not active at night and there is therefore an absence of organic carbon, which implies that the SRB were not able to conduct DSR in the dark (Rumbold, 2011). If this were the case, the sulphate concentration in the CW should increase at night, as was observed.

Although the ability of a slag matrix structure to sequestrate metal ions through a solid precipitation-sequestration process is well documented (Ziemkiewicz, 1998; Nehrehneim et al., 2008), literature relating to sulphate reduction could not be found. Further work is required to determine the mechanism of sulphate reduction in the slag-based bed, be it chemical, biochemical, physical or a combination thereof.

\section{CONCLUSIONS AND RECOMMENDATIONS}

From the results of the $\mathrm{pH}$, iron and sulphate tests presented, it was concluded that CWs, amended with BOF slag or charcoal, were able to effect some remediation on an AMD stream. Both slag- and charcoal-based CWs removed iron almost completely from the aqueous phase. It was noted that a slag amendment appeared to provide a better environment for sulphate reduction and was marginally more effective than charcoal at AMD treatment, although both CWs removed in excess of $75 \%$ of the sulphate in the feed.

The mechanisms of remediation were not fully elucidated but the BOF-amended CW probably effects remediation through chemico-physical processes whilst the charcoal CW effects remediation through physical, chemical and biological processes.
There is a need to conduct further research to better understand the microbial action underlying the iron and sulphate reduction. The long-term and maximum capacities of the systems also need to be understood as it has not yet been established how much AMD the slag can treat per unit mass, or the rate at which charcoal should be added to a charcoal-amended system. The iron filtration properties of the two systems will also be investigated in future research.

\section{ACKNOWLEDGEMENTS}

The authors thank the following individuals and groups for their contributions:

- Harsco Metals \& Minerals South Africa, for the supply of the BOF slag for this project

- Dr Karl Rumbold, of the School of Molecular and Cell Biology, University of the Witwatersrand for support

- Thanks to Dr Laura Millroy, of the Biosciences Division of the CSIR for her help and guidance in the development and research stages of the project

- Mrs Janet Walker, for the generous donation of the plants used in the experiment

- The support staff at the University of the Witwatersrand

\section{REFERENCES}

AKCIL A and KOLDAS S (2006) Acid Mine Drainage (AMD): Causes, treatment and case studies. J. Clean. Prod. 14 (12-13) 1139-1145.

BATTY LC (2003) Wetland plants - more than just a pretty face? Land Contam. Reclam. 11 (2) 173-180.

BATTY LC and YOUNGER PL (2004) Growth of Phragmites australis (Cav.) Trin ex. Steudel in mine water treatment wetlands: effects of metal and nutrient uptake. Environ. Pollut. 132 (1) 85-93.

BENNER SG, BLOWES DW, GOULD R, HERBERT RBJ and PTACEK CJ (1999) Geochemistry of a permeable reactive barrier for metals and acid mine drainage. Environ. Sci. Technol. 33 (16) 2793-2799.

BENNER SG, GOULD WD and BLOWES DW (2000) Microbial populations associated with the generation and treatment of acid mine drainage. Chem. Geol. 169 (3-4) 435-448.

CHRISTENSEN B, LAAKE M and LIEN T (1996) Treatment of acid mine water by sulfate-reducing bacteria; results from a bench scale experiment. Water Res. 30 (7) 1617-1624.

DIZ HR (1997) Chemical and biological treatment of acid mine drainage for the removal of heavy metals and acidity. $\mathrm{PhD}$ submission, Virginia Polytechnic Institute and State University. 89 pp.

DUSHENKOV V, KUMAR PBAN, MOTTO H and RASKIN I (1995) Rhizofiltration: the use of plants to remove heavy metals from aqueous streams. Environ. Sci. Technol. 29 (5) 1239-1245.

DVORAK DH, HEDIN RS, EDENBORN HM and MCINTIRE PE (1992) Treatment of metal-contaminated water using bacterial sulfate reduction: Results from pilot-scale reactors. Biotechnol. Bioeng. 40 (5) 609-616.

EMERSON D, WEISS JV and MEGONIGAL JP (1999) Ironoxidizing bacteria are associated with ferric hydroxide precipitates (Fe-plaque) on the roots of wetland plants. Appl. Environ. Microb. 65 (6) 2757-2761.

FENG D, VAN DEVENTER JSJ and ALDRICH C (2004) Removal of pollutants from acid mine wastewater using metallurgical byproduct slags. Sep. Purif. Technol. 40 (1) 61-67.

KADLEC RH, KNIGHT RL, VYMAZAL J, BRIX H, COOPER P and HABERL R (2000) Constructed Wetlands for Pollution Control: Processes, Performance, Design and Operation. IWA Publishing, London.

LABUSCHAGNE PF, USHER BH and MATFIELD F (2005), Geohydrological management approaches for site closure in South African gold mines. Proc. Conference on Processing and Disposal of Industrial and Mining Waste, 13-15 July 2005, Minerals Engineering International, Falmouth, United Kingdom. 
LINDSAY MBJ, BLOWES DW, CONDON PD and PTACEK CJ (2011) Organic carbon amendments for passive in situ treatment of mine drainage: Field experiments. Appl. Geochem. 26 (7) 1169-1183.

NEHRENHEIM E, WAARA $S$ and JOHANSSON WESTHOLM L (2008) Metal retention on pine bark and blast furnace slag On-site experiment for treatment of low strength landfill leachate. Bioresour. Technol. 99 (5) 998-1005.

PEPPAS A, KOMNITSAS K and HALIKIA I (2000) Use of organic covers for acid mine drainage control. Miner. Eng. 13 (5) 563-574.

POTGIETER-VERMAAK SS, POTGIETER JH, MONAMA P and

VAN GRIEKEN R (2006) Comparison of limestone, dolomite and fly ash as pre-treatment agents for acid mine drainage. Miner. Eng. 19 (5) 454-462.

RUMBOLD K (2011) Personal communication, 19 October 2011. Possible reasons for sulfate fluctuation. Dr Karl Rumbold, Senior Lecturer, School of Molecular and Cell Biology, University of the Witwatersrand, Johannesburg, Private Bag 3, WITS, 2050.

SHEORAN AS and SHEORAN V (2006) Heavy metal removal mechanism of acid mine drainage in wetlands: A critical review. Miner. Eng. 19 (2) 105-116.

SOUTHAFRICA.INFO (2013) Mining and minerals in South Africa. URL: http://www.southafrica.info/business/economy/sectors/mining.htm\#.USIntR2g3oI (Accessed 18 February 2013).

SQUIRES RC, COWAN JAC and WOOD FC (1983) The desalination of coalmine drainage water by reverse osmosis. Desalination 47 (1-3) 343-350.
TUTTLE J, DUGAN P and RANDLES C (1969) Microbial sulfate reduction and its potential utility as an acid mine water pollution abatement procedure. Appl. Microbiol. 17 (2) 297-302.

TUTU H, McCARTHY TS and CUKROWSKA E (2008) The chemical characteristics of acid mine drainage with particular reference to sources, distribution and remediation: The Witwatersrand Basin, South Africa as a case study. Appl. Geochem. 23 (12) 3666-3684.

USEPA (UNITED STATES ENVIRONMENTAL PROTECTION AGENCY) (1994) Technical Document: Acid Mine Drainage Prediction URL: http://water.epa.gov/polwaste/nps/upload/ amd.pdf (Accessed 18 Feb 2013). United States Environmental Protection Agency, Washington.

WALLACE SD and KNIGHT RL (2006) Small-Scale Constructed Wetland Treatment Systems. IWA Publishing, Vancouver.

WAYBRANT KR, BLOWES DW and PTACEK CJ (1998). A selection of reactive mixtures for use in permeable reactive walls for treatment of mine drainage. Environ. Sci. Technol. 32 (13) 1972-1979.

YOKLEY RA and LANCET MS (1987) Laboratory Scale Evaluation of Potential Lime Substitutes for AMD Treatment, Proc. $8^{\text {th }}$ Annual West Virginia Surface Mine Drainage Task Force Symposium, 7-8 April 1987, Morgantown, West Virginia.

YOUNGER PL (ed.) (1997) Minewater treatment using wetlands. Proc. National Conference of Mining. Chartered Institution of Water and Environmental Management (CIWEM), Newcastle Upon Tyne. 200 pp.

ZIEMKIEWICZ PF (1998) Steel slag: Applications for AMD control. Proc. Hazardous Waste Research Conference, 18-21 May 1998, Snowbird, Utah. 
http://dx.doi.org/10.4314/wsa.v39i3.4 Available on website http://www.wrc.org.za

ISSN 0378-4738 (Print) = Water SA Vol. 39 No 3 WISA 2012 Special Edition 2013 ISSN 1816-7950 (On-line) = Water SA Vol. 39 No 3 WISA 2012 Special Edition 2013 